Mustafa Kemal Yuzbasioglu'

PhD Student, Kastamonu University

Institute of Science, Kastamonu,Turkey

Prof. Dr. Mehmet Altan Kurnaz ${ }^{2}$

Kastamonu University

Kastamonu, Turkey
Original scientific paper

UDC: 37.014 .5

DOI: $10.5937 /$ IstrPed2102451Y

\title{
PRE-SERVICE TEACHERS' CARING ABOUT SUSTAINABLE DEVELOPMENT GOALS FOR TURKEY AND FOR THE WORLD AND THEIR COMPETENCE IN ASSOCIATING THE GOALS WITH THE LEARNING OUTCOMES IN THE CURRICULUM
}

\begin{abstract}
This study aims to determine pre-service science teachers' caring about the 2030 Sustainable Development Goals (SDG) for Turkey and for the world and their levels of competence in associating the SDG-related learning outcomes in the curriculum with these goals. The study employed the survey model, which is a descriptive research method. The study group consists of 60 pre-service science teachers. The data were collected through forms developed by the researchers, and descriptive statistics were used in the analysis of the data. The participating pre-service teachers regard SDG "very important" for both Turkey and the world. According to the findings of the study, there are gender-based differences between the pre-service teachers in terms of caring about SDG for Turkey and for the world. While nearly half of the pre-service teachers regard themselves partially competent in matching the learning outcomes in the science curriculum with SDG, they have some deficiencies in practice. To eliminate the pre-service teachers' deficiencies on sustainable development, the study recommends making adjustments in the curriculum implemented in Turkey with regards to the concept of sustainable development.
\end{abstract}

Keywords: Environment education, pre-service teachers, science curriculum, sustainable development, sustainable development goals.

\section{Introduction}

Needs and demands can bring along various problems. The limitedness of natural resources and the rapid increase in the world population narrow living areas and thus cause the environment to be damaged. Resources on earth may seem unlimited; but one day, they may not meet the needs of humanity. This situation highlights the concept of sustainable development to protect the future of humanity. Sustainable development refers to not taking away future generations' opportunities to meet their needs while meeting the needs of humanity today (Brundtland, 1987; Collin, 2004). In this regard, people should act with the thought that others will also use the world after them (Tietenberg, 2006). Natural resources used by humanity are relics that have been brought from the past to the present and should be transferred to the future. In order for the world to be a more livable place, there are some responsibilities that fall on

\footnotetext{
1 m.kemalyuzbasioglu@gmail.com

2altan.kurnaz@gmail.com
} 
humanity before disasters are experienced. Individuals must fulfill their responsibilities and use natural resources sustainably to protect the world today and tomorrow. Therefore, the concept of sustainable development is one of the fundamental points of a system that balances the relationship of human with the environment (Cross, 1998). Education plays an important role in humanity's access to sustainability (McKeown, Hopkins, Rizzi, \& Chrystalbride, 2002) and aims to raise individuals' awareness about the protection of the world they live in (Bakirci \& Yildirim, 2017; Bonnet, 1999; Haubrich, Reinfried, \& Schleicher, 2007; Howell \& Cartwright, 2009; Tanriverdi, 2009). With a quality education, the future can be built sustainably. To ensure sustainable development, education aims to raise individuals who make decisions for the benefit of today and of future generations. It helps people to improve their attitudes, knowledge, and skills related to sustainable development. Also, education plays an important role in the development of the systemic understanding and ideas required to grasp the complex links in sustainable development (Hofman-Bergholm, 2018). At the United Nations Sustainable Development Summit held in 2015, '2030 Sustainable Development Goals' (SDG) were determined to protect the future of the world (United Nations Development Programme, 2015). Countries that are members of the United Nations adopted 17 SDG, which include different subheadings, in order to eradicate poverty in all aspects and attain welfare for all humanity (see Appendix A for details). The aim of the goals on the agenda of the United Nations is to enable all humanity to continue their lives in better conditions and to leave a better world to the next generations. To achieve these goals, it is important that countries, individuals, and organizations, especially educators, are aware of sustainability.

Various actions are taken in Turkey in line with the 2030 SDG. In this context, Turkish Republic Presidency of Strategy and Budget examines the status of achieving SDG and makes evaluations at a national level (Turkish Republic Presidency of Strategy and Budget, 2019). Such evaluations guide the relevant institutions and organizations for achieving SDG. Individuals' awareness of sustainable development is highly important to achieve these goals. Turkey, like other countries, gives importance to education and training activities to provide individuals with such awareness. It is aimed to bring this awareness to students through a variety of courses and curricula. Science is one of the courses having an important share in achieving SDG due to the fact that it contains many learning outcomes related to natural resources, environment, and sustainability (Ministry of National Education, 2018). With science education, individuals can be provided with the necessary knowledge for a sustainable world (Stratton, Hagevik, Feldman, \& Bloom, 2015); and thus, the sustainable development of our world can be encouraged by raising responsible individuals for the future (Eilks, Nielsen, \& Hofstein, 2014). Science education aims to develop the knowledge and skills of individuals for them to be responsible citizens for a sustainable world as well as to think critically about science (Carter, 2008; Feldman \& Nation, 2015). Curricula have an important role in this (Faiz \& Bozdemir Yuzbasioglu, 2019; Powers, 2004; Tanriverdi, 2009). Science curriculum in Turkey has undergone many revisions in terms of learning domains and learning outcomes in accordance with the requirements and needs of the era (Yaz, Yuzbasioglu, \& Kurnaz, 2019; Yaz \& Kurnaz, 2020). The concept of 'Sustainable Development' is encountered within the special aims of the current science curriculum (MoNE, 2018). When the special aims of the curriculum are examined, it is seen that individuals are aimed to develop awareness of sustainable development related to society, economy, and natural resources by recognizing the interaction between the environment and society. Though the science curriculum in Turkey has been revised to include the latest developments, amendments or corrections may fall short of raising conscious individuals to create a sustainable future. Teachers, who students take as a model and interact with the most, have great responsibilities in transferring the SDG-related learning outcomes contained in the curriculum to students (Anyolo, Karkkainen, \& Keinonen, 2018; Hungerford, 2010; Kabadayi, 2016; Walls, 2011). Teachers need to keep their knowledge about sustainability up-to-date and 
follow developments on this matter (Salite, 2015). Therefore, pre-service teachers should be well-equipped in sustainable development before they graduate (Hofman-Bergholm, 2018). To raise individuals who will contribute to achieving SDG, it is very important that pre-service teachers have knowledge of SDG. The literature contains research exploring pre-service teachers' awareness of sustainable development (Cobanoglu \& Turer, 2015), their views and understandings about sustainability (Veisson \& Kabadayi, 2018), their responsibilities as teachers (Cross, 1998), and teaching practices related to sustainable development (Anyolo, Karkkainen, \& Keinonen, 2018). For sustainable development education to be provided to students, it is very important that teachers, who are actively involved in the acquisition of SDGrelated learning outcomes in curricula, care about the relevant goals and have the competence to associate these goals with the learning outcomes. This study aims to determine pre-service science teachers' caring about SDG for Turkey and for the world and their levels of competence in associating the related learning outcomes in the curriculum with these goals. To this end, the study seeks to answer the following questions:

1. How much do pre-service science teachers care about the UN 2030 SDG for Turkey and for the world?

2. How competent do pre-service science teachers regard themselves in associating the learning outcomes in the curriculum with SDG?

3. How competent are pre-service science teachers in associating the learning outcomes in the curriculum with SDG?

\section{Method}

The study employs the survey model, which is a descriptive research method. This method is reported to be effective in describing or explaining a situation (Cohen, Manion, \& Morrison, 2007; Karasar, 2002). This method was adopted as the study attempted to determine the preservice science teachers' levels of caring about the UN 2030 SDG for Turkey and for the world, how competent they regard themselves in associating the SDG-related learning outcomes with these goals, and their actual levels of associating the outcomes with the goals, thereby revealing an existing situation.

\section{Study Group}

The study group consists of a total of 60 pre-service science teachers, 12 male and 48 female, who were studying in the fourth grade in an education faculty located in the Western Black Sea Region of Turkey in the 2019-2020 academic year. The participants were determined using criterion sampling, a non-random sampling method. Criterion sampling involves selecting participants based on pre-determined criteria (Patton, 1997). When the curricula of the education faculty are examined, it is seen that the courses including the content of environment, environmental problems, and sustainability are in the science education curriculum. Also, we also think that science teachers will play a more active role in designing learning environments on these concepts. For this reason, taking the courses involving the above-mentioned subjects and being a fourth-grade student, which refers to the closest grade level to professional teaching, were determined as criteria for participation.

\section{Data Collection Tool}

The "Caring About Sustainable Development Goals Form", the "Competence in Associating Sustainable Development Goals with Learning Outcomes Form", and the "Associating Sustainable Development Goals with Learning Outcomes Form" were used for data collection. The Caring About Sustainable Development Goals Form is a 4-point Likert-type form 
(unimportant-partially important-important-very important) and consists of 17 items. These items are composed of the UN 2030 SDG. With that form, the pre-service teachers were asked about their caring about each goal (see Appendix A for details). The Competence in Associating Sustainable Development Goals with Learning Outcomes Form is also comprised of these items. It is a 3-point Likert-type form (incompetent-partially competent-competent). With that form, the pre-service teachers were asked whether they regarded themselves competent in associating the learning outcomes in the curriculum with SDG. The Associating Sustainable Development Goals with Learning Outcomes Form consists of 40 items. These items consist of the learning outcomes related to sustainability included in the Science Curriculum for the 5 th to 8th grades determined by the researchers. Validity and reliability studies of the said data collection tools were conducted. Two experts expressed their opinions concerning the measurement tools in terms of scientific suitability, suitability for the purpose of the study, and the language used. Based on their views, some necessary adjustments were made. To determine the SDG-related learning outcomes, firstly the learning outcomes in the science curriculum (MoNE, 2018) were scanned and associated with SDG by two researchers. Researchers came together, discussed the associations, and found a middle ground. In this way, the SDG-related learning outcomes were determined. In addition, an independent researcher with research on environmental education and sustainability was asked to associate the relevant learning outcomes with SDG. The reliability formula proposed by Miles \& Huberman (1994) was used for the associations made by the independent researcher and those made by the researchers. As a result, the agreement between the two analyses was found to be $97.5 \%$. Since the reliability calculations above $70 \%$ are accepted as reliable for a particular study (Miles \& Huberman, 1994), the analyses made in the present study were assumed to be sufficient and reliable.

\section{Data Analysis}

Descriptive statistics were used in the analysis of data. The data obtained from the Caring About Sustainable Development Goals Form showed the extent to which the pre-service science teachers cared about each of SDG for Turkey and for the world, and the participants' answers were classified as unimportant, partially important, important, and very important. This classification was made according to the mean scores calculated based on the answers given by the pre-service teachers. The score ranges in this classification are as follows: 1.00-1.74: unimportant; 1.75-2.49: partially important; $2.50-3.24$ : important; 3.25-4.00: very important. The data obtained from the Competence in Associating Sustainable Development Goals with Learning Outcomes Form were analyzed through frequency and percentage calculations over the answers the pre-service teachers gave with regards to their competence in associating the SDG-related learning outcomes in the curriculum with SDG. In the Associating Sustainable Development Goals with Learning Outcomes Form, the pre-service science teachers associated 40 learning outcomes related to SDG in the 5th to 8th grades with 17 SDG. Those association levels were classified as incompetent, partially competent, and competent. In the association of the learning outcomes with SDG, matching with the wrong goal/s fell under the "incompetent" category, matching with the wrong goal/s as well as with true goal/s under the "partially competent" category, and matching with completely true goal/s under the "competent" category.

\section{Findings}

The findings of the study are presented below in the order of the sub-problems. Table 1 presents to what extent the pre-service teachers care about UN 2030 SDG for Turkey and for the world based on gender and overall. 
Table 1. Pre-service Male and Female Teachers' Status of Caring about the UN 2030 SDG for Turkey and for the World

\begin{tabular}{ccccccc} 
& \multicolumn{3}{c}{ Turkey } & \multicolumn{2}{c}{ World } & \multicolumn{2}{c}{ Male } & Female & $\overline{\text { Total }}$ \\
\cline { 2 - 7 } Goal (G) & $\begin{array}{c}\text { Male } \\
\overline{\mathbf{X}}\end{array}$ & $\begin{array}{c}\text { Female } \\
\overline{\mathbf{X}}\end{array}$ & $\begin{array}{c}\text { Total } \\
\overline{\mathbf{X}}\end{array}$ & $\overline{\mathbf{X}}$ & $\overline{\mathbf{X}}$ & 3.40 \\
\hline G 1 & 3.58 & 3.63 & 3.62 & 3.25 & 3.44 & 3.40 \\
G 2 & 3.92 & 3.65 & 3.70 & 3.58 & 3.44 & 3.47 \\
G 3 & 3.67 & 3.65 & 3.65 & 3.08 & 3.44 & 3.37 \\
G 4 & 3.58 & 3.73 & 3.70 & 3.25 & 3.62 & 3.55 \\
G 5 & 3.75 & 3.85 & 3.83 & 3.58 & 3.73 & 3.70 \\
G 6 & 3.25 & 3.77 & 3.67 & 3.33 & 3.71 & 3.63 \\
G 7 & 3.33 & 3.65 & 3.58 & 3.17 & 3.54 & 3.47 \\
G 8 & 3.67 & 3.62 & 3.63 & 3.25 & 3.48 & 3.43 \\
G 9 & 3.67 & 3.67 & 3.67 & 3.42 & 3.48 & 3.47 \\
G 10 & 3.25 & 3.67 & 3.58 & 3.25 & 3.52 & 3.47 \\
G 11 & 3.42 & 3.81 & 3.73 & 3.33 & 3.58 & 3.53 \\
G 12 & 3.42 & 3.75 & 3.68 & 3.42 & 3.56 & 3.53 \\
G 13 & 3.42 & 3.60 & 3.57 & 3.58 & 3.58 & 3.58 \\
G 14 & 3.58 & 3.71 & 3.68 & 3.50 & 3.75 & 3.70 \\
G 15 & 3.42 & 3.79 & 3.72 & 3.67 & 3.67 & 3.67 \\
G 16 & 3.50 & 3.81 & 3.75 & 3.42 & 3.67 & 3.62 \\
G 17 & 3.25 & 3.69 & 3.60 & 3.50 & 3.65 & 3.62 \\
\hline Overall View & 3.51 & 3.71 & 3.67 & 3.39 & 3.58 & 3.54 \\
\hline
\end{tabular}

Table 1 shows that the participating pre-service teachers care about SDG for Turkey and for the world at the "very important" level both overall and for each of 17 goals. While the pre-service teachers' mean score for caring about SDG for Turkey is 3.67, their mean score for caring about SDG for the world is 3.54. The male pre-service teachers' mean score for caring about SDG overall for Turkey is 3.51. When the goals are examined individually for the male pre-service teachers, the goals with the lowest mean score for caring about for Turkey (3.25) are G6 (Clean water and sanitation), G10 (Reduced inequalities), and G17 (Partnerships for the goals) while the goal with the highest mean score (3.92) is G2 (zero hunger). The female pre-service teachers' mean score for caring about SDG overall for Turkey is 3.71. When the goals are examined individually for the female pre-service teachers, the goal with the lowest mean score for caring about for Turkey (3.60) is $\mathrm{G} 13$ (Climate action) while the goal with the highest mean score (3.85) is $\mathrm{G}_{5}$ (Gender equality).

The pre-service teachers' mean score for caring about SDG overall for the world corresponds to the "very important" level. When the goals are examined individually, it is seen that the male and female pre-service teachers care about SDG at different levels. The male pre-service teachers' mean score for caring about SDG for the world is 3.39, corresponding to the "very important" level. When the goals are examined individually for the male teachers, the goal with the lowest mean score for caring about for the world (3.08), corresponding to the "important" level, is $\mathrm{G}_{3}$ (Good health and well-being) while the one with the highest mean score (3.67), corresponding to the "very important" level, is G15 (Life on land). The female pre-service teachers' mean score for caring about SDG for the world is 3.58, corresponding to the "very important" level. When the goals are examined individually for the female teachers, the goals with the lowest mean score for caring about for the world (3.44) are G1 (No poverty), G2 (Zero hunger), and $\mathrm{G}_{3}$ (Good health and well-being) while the one with the highest mean score (3.75) is G14 (Life below water). 
Figure 1 presents the pre-service teachers' mean scores for caring about SDG for Turkey and for the world on the basis of each goal.

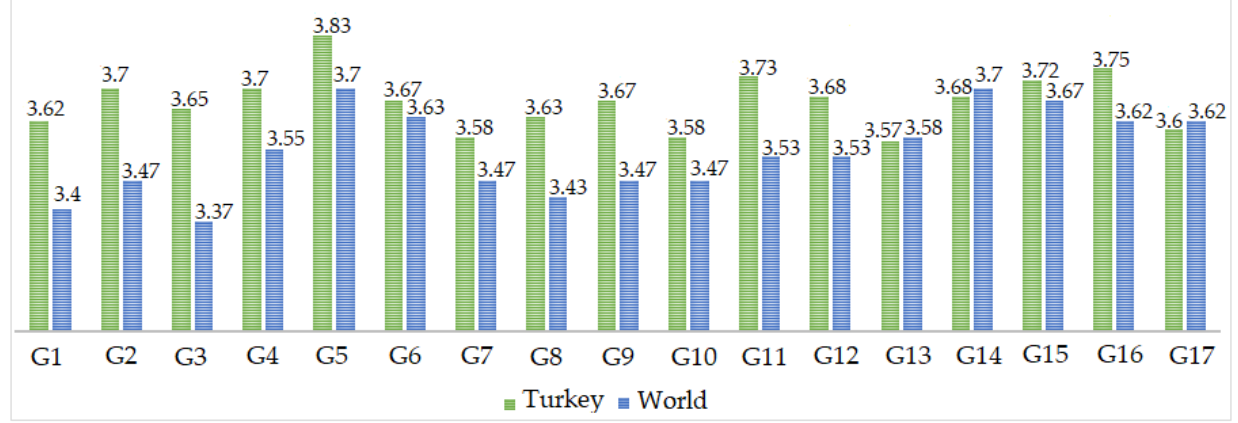

Figure 1. Pre-service teachers' status of caring about the UN 2030 SDG for Turkey and for the world.

As shown in Figure 1, the goal cared about most for Turkey is $\mathrm{G}_{5}$ (Gender equality) with a mean score of 3.83 and the one cared about least is $\mathrm{G}_{13}$ (Climate action) with a mean score of 3.57. For the world, on the other hand, the goals cared about most are $\mathrm{G}_{5}$ (Gender equality) and $\mathrm{G}_{14}$ (Life below water) and the one cared about least is $\mathrm{G}_{3}$ (Good health and well-being) with a mean score of 3.37. When a comparison is made between caring about SDG for Turkey and caring about SDG for the world based on each goal, it is seen that G1 (No poverty), G2 (Zero hunger), $G_{3}$ (Good health and well-being), G4 (Quality education), $G_{5}$ (Gender equality), G6 (Clean water and sanitation), G7 (Affordable and clean energy), G8 (Decent work and economic growth), G9 (Industry, innovation and infrastructure), G10 (Reduced inequalities), G11 (Sustainable cities and communities), G12 (Responsible consumption and production), G15 (Life on land), and G16 (Peace, justice and strong institutions) are cared about more for Turkey than for the world. On the other hand, the pre-service teachers care about $\mathrm{G} 13$ (Climate action), G14 (Life below water), and G17 (Partnerships for the goals) more for the world than for Turkey. The biggest difference between the mean scores for caring about the goals for Turkey and for the world is in $\mathrm{C}_{3}$ (Good health and well-being) in favour of Turkey. The smallest difference between the mean scores for caring about the goals for Turkey and for the world is in G13 (Climate action) in favour of the world.

Table 2 presents the pre-service teachers' views of their competence in associating the learning outcomes in the science curriculum with the UN 2030 SDG by gender and overall.

Table 2. The pre-service teachers' views of their competence in associating the learning outcomes in the science curriculum with SDG

\begin{tabular}{|c|c|c|c|c|c|c|c|c|c|}
\hline & \multicolumn{3}{|c|}{ Male } & \multicolumn{3}{|c|}{ Female } & \multicolumn{3}{|c|}{ Overall } \\
\hline & 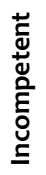 & 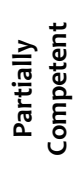 & 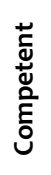 & 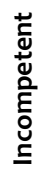 & 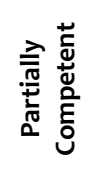 & 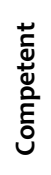 & 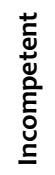 & 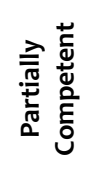 & 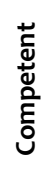 \\
\hline $\begin{array}{c}\text { Goal } \\
\text { (G) }\end{array}$ & $f$ & $f$ & $f$ & $f$ & $f$ & $f$ & $f$ & $f$ & $f$ \\
\hline G 1 & - & 10 & 2 & 8 & 28 & 12 & 8 & 38 & 14 \\
\hline$G_{2}$ & 2 & 4 & 6 & 11 & 20 & 17 & 13 & 24 & 23 \\
\hline
\end{tabular}




\begin{tabular}{|c|c|c|c|c|c|c|c|c|c|}
\hline$G_{3}$ & 3 & 4 & 5 & 5 & 28 & 15 & 8 & 32 & 20 \\
\hline$G_{4}$ & 2 & 7 & 3 & 4 & 22 & 22 & 6 & 29 & 25 \\
\hline$G_{5}$ & 2 & 6 & 4 & 10 & 7 & 31 & 12 & 13 & 35 \\
\hline G 6 & 3 & 7 & 2 & 8 & 27 & 13 & 11 & 34 & 15 \\
\hline G 7 & 3 & 6 & 3 & 14 & 27 & 7 & 17 & 33 & 10 \\
\hline G 8 & 2 & 7 & 3 & 11 & 22 & 15 & 13 & 29 & 18 \\
\hline G 9 & 6 & 3 & 3 & 17 & 22 & 9 & 23 & 25 & 12 \\
\hline$G_{10}$ & 5 & 6 & 1 & 16 & 20 & 12 & 21 & 26 & 13 \\
\hline G 11 & 4 & 5 & 3 & 8 & 23 & 17 & 12 & 28 & 20 \\
\hline$G_{12}$ & 4 & 5 & 3 & 3 & 25 & 20 & 7 & 30 & 23 \\
\hline$G_{13}$ & 3 & 4 & 5 & 8 & 28 & 12 & 11 & 32 & 17 \\
\hline $\mathrm{G}_{14}$ & 3 & 6 & 3 & 11 & 27 & 10 & 14 & 33 & 13 \\
\hline G 15 & 2 & 7 & 3 & 9 & 27 & 12 & 11 & 34 & 15 \\
\hline G 16 & 1 & 7 & 4 & 13 & 20 & 15 & 14 & 27 & 19 \\
\hline G 17 & 3 & 7 & 2 & 11 & 26 & 11 & 14 & 33 & 13 \\
\hline$f$ & 48 & 101 & 55 & 167 & 399 & 250 & 215 & 500 & 305 \\
\hline$\%$ & 23.53 & 49.51 & 26.96 & 20.46 & 48.90 & 30.64 & 21.08 & 49.02 & 29.90 \\
\hline
\end{tabular}

Table 2 shows the classification of the male and female pre-service teachers in terms of regarding themselves competent in matching the goals with the learning outcomes. $49.51 \%$ of the male pre-service teachers regard themselves "partially competent", 26.96\% "competent", and $23.53 \%$ "incompetent". On the other hand, $48.90 \%$ of the female pre-service teachers regard themselves "partially competent", 30.64\% "competent", and 20.46\% “incompetent". Considering all of the pre-service teachers participating in the study, it is evident that $49.02 \%$ of them regard themselves "partially competent" while others regard themselves "competent" (29.30\%) and "incompetent" (21.08\%).

The male pre-service teachers regard themselves competent in matching learning outcomes with goals most in G2 (Zero hunger) and least in G10 (Reduced inequalities). On the other hand, the female pre-service teachers regard themselves competent in matching learning outcomes with goals most in $\mathrm{G}_{5}$ (Gender equality) and least in G7 (Affordable and clean energy).

Table 3 presents the pre-service teachers' competence in associating the SDG-related learning outcomes in the curriculum with the goals.

Table 3. The pre-service teachers' competence in associating the learning outcomes included in the curriculum with SDG

\begin{tabular}{|c|c|c|c|c|c|c|c|c|c|}
\hline \multirow[b]{2}{*}{ 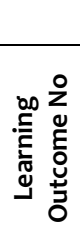 } & \multicolumn{3}{|c|}{ Male } & \multicolumn{3}{|c|}{ Female } & \multicolumn{3}{|c|}{ Overall } \\
\hline & 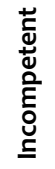 & 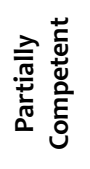 & 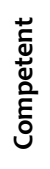 & 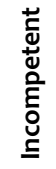 & 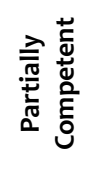 & 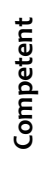 & 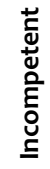 & 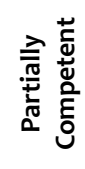 & 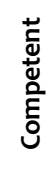 \\
\hline 1 & 12 & - & - & 46 & 2 & - & 58 & 2 & - \\
\hline 2 & 5 & 7 & - & 8 & 40 & - & 13 & 47 & - \\
\hline
\end{tabular}




\begin{tabular}{|c|c|c|c|c|c|c|c|c|c|}
\hline 3 & 2 & 10 & - & 4 & 44 & - & 6 & 54 & - \\
\hline 4 & 8 & 4 & - & 28 & 20 & - & 36 & 24 & - \\
\hline 5 & 7 & 5 & - & 27 & 21 & - & 34 & 26 & - \\
\hline 6 & 9 & 3 & - & 24 & 24 & - & 33 & 27 & - \\
\hline 7 & 9 & 3 & - & 22 & 26 & - & 31 & 29 & - \\
\hline 8 & 10 & 2 & - & 37 & 9 & 2 & 47 & 11 & 2 \\
\hline 9 & 3 & 9 & - & 21 & 27 & - & 24 & 36 & - \\
\hline 10 & 11 & 1 & - & 34 & 14 & - & 45 & 15 & - \\
\hline 11 & 12 & - & - & 37 & 4 & 7 & 49 & 4 & 7 \\
\hline 12 & 10 & 2 & - & 39 & 9 & - & 49 & 11 & - \\
\hline 13 & 12 & - & - & 37 & 5 & 6 & 49 & 5 & 6 \\
\hline 14 & 12 & - & - & 47 & - & 1 & 59 & - & 1 \\
\hline 15 & 7 & 4 & 1 & 33 & 9 & 6 & 40 & 13 & 7 \\
\hline 16 & 4 & 7 & 1 & 31 & 17 & - & 35 & 24 & 1 \\
\hline 17 & 8 & 2 & 2 & 29 & 13 & 6 & 37 & 15 & 8 \\
\hline 18 & 7 & 5 & - & 30 & 18 & - & 37 & 23 & - \\
\hline 19 & 9 & 3 & - & 35 & 12 & 1 & 44 & 15 & 1 \\
\hline 20 & 11 & 1 & - & 43 & 5 & - & 54 & 6 & - \\
\hline 21 & 7 & 5 & - & 23 & 25 & - & 30 & 30 & - \\
\hline 22 & 10 & 2 & - & 27 & 21 & - & 37 & 23 & - \\
\hline 23 & 7 & 5 & - & 45 & 3 & - & 52 & 8 & - \\
\hline 24 & 10 & 2 & - & 41 & 7 & - & 51 & 9 & - \\
\hline 25 & 11 & 1 & - & 45 & 1 & 2 & 56 & 2 & 2 \\
\hline 26 & 7 & 5 & - & 36 & 12 & - & 43 & 17 & - \\
\hline 27 & 11 & 1 & - & 41 & 5 & 2 & 52 & 6 & 2 \\
\hline 28 & 9 & 3 & - & 38 & 10 & - & 47 & 13 & - \\
\hline 29 & 9 & 2 & 1 & 23 & 14 & 11 & 32 & 16 & 12 \\
\hline 30 & 6 & 6 & - & 25 & 23 & - & 31 & 29 & - \\
\hline 31 & 5 & 7 & - & 27 & 21 & - & 32 & 28 & - \\
\hline 32 & 7 & 5 & - & 32 & 16 & - & 39 & 21 & - \\
\hline 33 & 5 & 7 & - & 31 & 17 & - & 36 & 24 & - \\
\hline 34 & 11 & 1 & - & 36 & 12 & - & 47 & 13 & - \\
\hline 35 & 7 & 5 & - & 25 & 23 & - & 32 & 28 & - \\
\hline 36 & 9 & 3 & - & 26 & 22 & - & 35 & 25 & - \\
\hline 37 & 11 & 1 & - & 32 & 9 & 7 & 43 & 10 & 7 \\
\hline 38 & 7 & 5 & - & 26 & 20 & 2 & 33 & 25 & 2 \\
\hline 39 & 7 & 5 & - & 25 & 23 & - & 32 & 28 & - \\
\hline 40 & 8 & 4 & - & 19 & 29 & - & 27 & 33 & - \\
\hline$f$ & 332 & 143 & 5 & 1235 & 632 & 53 & 1567 & 775 & 58 \\
\hline$\%$ & 69.17 & 29.79 & 1.04 & 64.32 & 32.92 & 2.76 & 65.29 & 32.29 & 2.42 \\
\hline
\end{tabular}

Table 3 shows the male and female pre-service teachers' competence in associating the SDGrelated learning outcomes in the curriculum with the goals. The male pre-service teachers are "incompetent" in associating $69.17 \%$ of the learning outcomes with the goals while "partially 
competent" in associating $29.79 \%$ of the learning outcomes and "competent" in associating $1.04 \%$ of the learning outcomes. The female pre-service teachers are "incompetent" in associating $64.32 \%$ of the learning outcomes with the goals while "partially competent" in associating $32.92 \%$ of the learning outcomes and "competent" in associating $2.76 \%$ of the learning outcomes. Of the pre-service teachers, $2.42 \%$ fall under the "competent" category in associating the SDG-related learning outcomes in the curriculum with the goals while $32.29 \%$ fall under the "partially competent" category and 65.29\% under the "incompetent" category.

All of the male pre-service teachers failed to associate the learning outcomes $1,11,13$, and 14 with the goals and were thus classified as "incompetent". The male pre-service teachers were most successful in associating the learning outcome 17 , and two pre-service teachers were able to associate the learning outcome with the goal. The female pre-service teachers, on the other hand, were not categorized as absolutely "incompetent" in associating a learning outcome with a goal. The most successful learning outcome-goal matching was achieved in the learning goal 29 as 11 female pre-service teachers fell under the "competent" category. The pre-service teachers were most competent in matching the learning outcome 29 with the relevant goal. 12 pre-service teachers matched this learning outcome with the relevant goal at the "competent" level.

\section{Discussion and Conclusion}

This study firstly determined to what extent the pre-service science teachers care about the UN 2030 SDG for Turkey and for the world. Then the study investigated how competent the preservice teachers regard themselves in associating the learning outcomes in the science curriculum with the goals. Lastly, their actual levels of associating the related learning outcomes with the goals were determined.

The pre-service teachers regard SDG "very important" for Turkey and for the world. A comparison between their levels of caring about SDG for Turkey and for the world indicates that they care about SDG for Turkey more. They regard all goals "very important" for Turkey. The goal the pre-service teachers care about most for Turkey is $G_{5}$ (Achieve gender equality and empower all women and girls). Ozmete \& Ozdemir (2015) examined social structure and sustainable development indicators in Turkey. In this context, they described gender equality as the active participation of women, who make up around half of the society, in economic and social life and indicated it as a factor that forms the basis of the understanding of sustainable development. Turkey has taken important steps within the scope of $\mathrm{G}_{5}$ (Gender equality) as part of SDG policies, introduced various regulations on gender equality, women's health, and education and employment in particular, and made efforts to put them into practice (Turkish Republic Presidency of Strategy and Budget, 2019). That the pre-service teachers care about gender equality for Turkey most, as a finding of the present study, can be seen as a positive result in terms of achieving SDG. The goal the pre-service teachers care about least is G13 (Take urgent action to combat climate change and its impacts). That the pre-service teachers care about combatting climate change and its impacts least for Turkey may result from that they do not regard it as a global issue. This finding shows that the pre-service teachers are of the opinion that climate change and its impacts do not affect Turkey as much as they do other countries. This may be due to lack of knowledge regarding the causes, effects, and consequences of climate change. As a matter of fact, the literature on this subject contains studies reporting that pre-service teachers have imperfect knowledge and misconceptions on this matter (Khalid, 2003; Urey, Colak, Bozdemir Yuzbasioglu, \& Kaymakci, 2020). 
According to the findings of the present study, there are gender-based differences between the pre-service teachers in terms of caring about SDG for Turkey and for the world. The female pre-service teachers care about SDG for both Turkey and for the world more than the male preservice teachers do. The literature contains studies concluding, consistently with this finding of the present study, that women are more interested in environmentally friendly behaviors and exhibit more environmentally friendly behaviors than men (Tindall, Davies, \& Mauboules, 2003; Zelezny, Chua, \& Aldrich, 2000). As reasons for this, it is stated that women are mothers or future mothers (Sama, 2003) and that they are more social than men in daily life and have more concerns about environmental issues (Tuncer, Ertepinar, Tekkaya, \& Sungur). In terms of caring about SDG for Turkey, the lowest mean score of the female teachers is for G13 (Take urgent action to combat climate change and its impacts) while their highest mean score is for $\mathrm{G} 5$ (Achieve gender equality and empower all women and girls). On this, the lowest mean score of the male teachers is for $\mathrm{G} 6$ (Ensure the availability and sustainable management of water and sanitation for all), G10 (Reduce inequality within and among countries), and G17 (Strengthen the means of implementation and revitalize the global partnership for sustainable development) while their highest mean score is for G2 (End hunger, achieve food security and improved nutrition and promote sustainable agriculture). Based on these findings, it can be said that the male pre-service teachers care about primary needs such as nutrition for Turkey while the female pre-service teachers care about social issues such as gender equality.

In terms of caring about SDG for the world, the highest mean score is for G5 (Achieve gender equality and empower all women and girls) and G14 (Conserve and sustainably use the oceans, seas and marine resources for sustainable development). On this, the lowest mean score is for $\mathrm{G}_{3}$ (Ensure healthy lives and promote well-being for all at all ages). Neumayer (2004) defines sustainable development as the necessity of preserving the capacity of the world in order to provide well-being that does not decrease day by day. The concepts of sustainability and wellbeing are concepts that should be considered together. Poverty is a problem not only of economically undeveloped countries, but also of developed and developing countries (Arpacioglu Ozdemir, \& Oguz, 2018). Poverty significantly affects a large portion of the world's population. The fact that $\mathrm{G}_{3}$ (Good health and well-being) is the goal that the pre-service teachers care about least can be seen as a deficiency for achieving SDG. There are gender-based differences between the pre-service teachers in terms of caring about SDG for the world. In terms of caring about SDG for the world, the lowest mean score of the male pre-service teachers is for $\mathrm{C}_{3}$ (Ensure healthy lives and promote well-being for all at all ages) while the highest mean score is for $\mathrm{G} 15$ (Protect, restore and promote sustainable use of terrestrial ecosystems, sustainably manage forests, combat desertification, and halt and reverse land degradation and halt biodiversity loss). On this, the lowest mean score of the female pre-service teachers is for G1 (End poverty in all its forms everywhere), G2 (End hunger, achieve food security and improved nutrition and promote sustainable agriculture), and $\mathrm{G}_{3}$ (Ensure healthy lives and promote well-being for all at all ages) while their highest mean score is for $\mathrm{G} 14$ (Conserve and sustainably use the oceans, seas and marine resources for sustainable development). There are gender-based differences between the pre-service teachers in terms of caring about SDG for the world just like for Turkey. While the men care about the protection of the terrestrial ecosystem, the women care about the protection of the aquatic ecosystem. This finding shows that the pre-service teachers also care about living beings other than human beings and they think that all countries should care about this. In parallel with this, the literature also contains studies on caring about the environment and the living beings in it (Bozdemir \& Faiz, 2018; Casey \& Scott, 2006; Kortenkamp \& Moore, 2001).

Teachers use the curriculum both as a guide and as a source of information, which shapes their existing knowledge. It is thought that knowledge is forgotten when not used, and very little 
new knowledge is created over time (Arzi \& White, 2008). For this reason, it will be useful for teachers to care about and use the knowledge they have acquired. 14 pre-service teachers participating in the present study care about 14 SDG more for Turkey. They care about the remaining 3 SDG (G13 [Take urgent action to combat climate change and its impacts], G14 [Conserve and sustainably use the oceans, seas and marine resources for sustainable development], and G17 [Strengthen the means of implementation and revitalize the global partnership for sustainable development] more for the world than for Turkey. This finding shows that the pre-service teachers regard the issues of climate change, protection of the aquatic ecosystem, and global partnership for sustainable development more important for the world than for Turkey and that attention should paid to them. The biggest difference between the mean scores for caring about the goals for Turkey and for the world is in $\mathrm{G}_{3}$ (Ensure healthy lives and promote well-being for all at all ages) in favor of Turkey. The least difference is in $\mathrm{G} 13$ (Take urgent action to combat climate change and its impacts) in favor of the world. This demonstrates that the pre-service teachers care about healthy and quality life for Turkey more compared to the world. One of the striking results obtained in the study is on water. As is known, water is an indispensable element for living beings to survive. Although a great part of the earth's surface is covered with water, the amount of fresh water that people can use is very small. The limited clean and potable water increases the importance of water and causes it to be a strategic resource. The world population rising from the past to the present has greatly increased water consumption. Situations such as insufficiency of water sources, global warming, pollution of existing sources, and industrialization affect the potable water sources negatively (Gunduz \& Bilir, 2012; Kelly \& Fong, 2015). Considering the annual amount of fresh water per person, Turkey is in danger of being "water poor" in the future even if it is surrounded by sea (Karadag, 2008). For all of these reasons, Turkey and other countries should make water sustainable for the future of the world. To this end, it is very important that individuals are raised with awareness and consciousness of water (Ergin, 2008). According to the present study, the pre-service teachers mostly find themselves partially competent in matching $\mathrm{G} 6$ (Clean water and sanitation) with the learning outcomes. This goal is considered important for Turkey and for the world at a moderate level relative to other goals. It is reported in the literature that pre-service teachers have a lack of knowledge about water (Cakmak, Cakmak, \& Topal, 2018). It is thought that teachers who will raise the individuals of the future should have more awareness and care about water.

In the second stage of the study, the pre-service science teachers' status of regarding themselves competent in associating the learning outcomes in the curriculum with SDG were investigated. According to the findings, almost half of the pre-service teachers regard themselves partially competent in matching the learning outcomes in the science curriculum with SDG. The pre-service teachers' such partially competent perceptions may be due to not taking courses directly related to SDG. The literature suggests that pre-service teachers' selfefficacy in teaching subjects and concepts within the scope of the relevant courses increases when they take courses related to the subjects they will teach (Effeney \& Davis, 2013; Tokicin, Kurnaz, \& Yuzbasioglu, 2020; Yuzbasioglu \& Kurnaz, 2019). The present study detected no gender-based difference between the pre-service teachers in terms of regarding themselves competent. The male pre-service teachers regard themselves competent most in matching the learning outcomes with G2 (End hunger, achieve food security and improved nutrition and promote sustainable agriculture) and least in matching them with $\mathrm{G} 10$ (Reduce inequality within and among countries). As to the female pre-service teachers, they regard themselves competent most in $\mathrm{G}_{5}$ (Achieve gender equality and empower all women and girls) and least in $G 7$ (Ensure access to affordable, reliable, sustainable and modern energy for all). 
When the pre-service teachers were asked to associate the SDG-related learning outcomes in the curriculum with the goals, differences were identified between how competent they regarded themselves and their actual performance in practice. $2.42 \%$ of the pre-service teachers were found to be competent in associating the related outcomes with the goals. Before they matched, they had regarded themselves competent at the level of $29.9 \% .32 .29 \%$ of the preservice teachers were classified as "partially competent" and $65.29 \%$ as "incompetent" in matching the goals with the learning outcomes. Curricula and teachers who put them into practice play an active role in raising conscious individuals who will treat the world we live in as a trust to be passed on to future generations. Although curricula contain innovations, teachers may have problems in transferring these innovations to learning environments (Aydin \& Cakiroglu, 2010). Therefore, pre-service teachers should be aware of SDG before starting their professional life (Anyolo, Karkkainen, \& Keinonen, 2018; Walls, 2011). It was determined that although the pre-service teachers regarded themselves competent on the subject of sustainability, they were not as successful as they stated and had deficiencies in practice. Cobanoglu \& Turer (2015) reached a similar conclusion in their study with pre-service science teachers and stated that the pre-service teachers' knowledge on sustainable development was imperfect. Hence, the inclusion of concepts related to SDG in the curriculum does not mean that teachers are competent on this matter. Chatzifotiou (2006) found out that even though the concept of sustainable development was included in the UK curriculum, the teachers were not competent in discussing the concept of sustainability. Hence, for our sustainable future, it is very important for pre-service teachers to be educated on this subject before starting their profession (Hofman-Bergholm, 2018). It is also thought that it would be beneficial to include sustainable development in existing courses further to address the concept in depth (Anyolo, Karkkainen, \& Keinonen, 2018).

The present study detected gender-based differences between the pre-service teachers in terms of matching the learning outcomes with the goals. The male and female pre-service teachers were determined to be competent or incompetent in different learning outcomes though they received education in the same program. The use of tools and environments that attract the attention of individuals is important when creating learning environments for sustainability (Salite, 2008). The gender-based difference between the pre-service teachers in terms of matching SDG with the learning outcomes may be due to their different interests and caring levels.

\section{Recommendations}

Though the pre-service teachers regard SDG important for Turkey and for the world and consider themselves competent in matching learning outcomes with the goals, they have problems in associating the relevant learning outcomes with the goals. To eliminate such deficiencies of pre-service teachers, adjustments may be made in the curricula implemented in Turkey with regards to the concept of sustainable development. We think that it would be beneficial to draw more attention to and emphasize SDG especially in environment-oriented classes in the course of training of teachers.

Although the pre-service teachers deemed themselves highly competent in matching the learning outcomes with the SDG, they had problems when they were asked to match. This shows that the pre-service teachers have deficiencies in reading the learning outcomes. Research may be conducted to overcome this deficiency.

Future research may also examine Turkey's SDG evaluation report and explore how consistent the science curriculum is with the goals achieved or intended to be achieved. We think that a 
curriculum implemented with relevant adjustments will help to eliminate the above-mentioned deficiencies.

\section{References:}

Anyolo, E. O., Karkkainen, S., \& Keinonen, T. (2018). Implementing education for sustainable development in Namibia: School teachers' perceptions and teaching practices. Journal of Teacher Education for Sustainability, 20(1), 64-81.

Arpacioglu Ozdemir, O., \& Oguz, I. H. (2018). A case of poverty from the perspective of sustainable development. Journal of International Social Research, 11(55), 769-781.

Arzi, H. J. \& White, R. T. (2008). Change in teachers' knowledge of subject matter: A 17 years longitudinal study. Science Education, 92, 221-251.

Aydin, S. \& Cakiroglu, J. (2010). Teachers' views related to the new science and technology curriculum: Ankara case. Elementary Education Online, 9(1), 301-315.

Bakirci, H. \& Yildirim, I. (2017). The influence of common knowledge construction model on students' conceptual understanding and permanence of knowledge in terms of greenhouse effect. Journal of Kirsehir Education Faculty, 18(Special Issue), 45-63.

Bonnett, M. (1999). Education for sustainable development: a coherent philosophy for environmental education? Cambridge Journal of Education, 29(3), 313-324.

Bozdemir, H. \& Faiz, M. (2018). Ecocentric, anthropocentric and antipathetic attitudes of teacher candidates towards the environment. Sakarya University Journal of Education, $8(1), 61-75$.

Bruntland, G. H. (1987). Our common future: the world commission on environment and development. Oxford: Oxford University Press.

Cakmak, M., Cakmak, R., \& Topal, G. (2018). Level of knowledge and misconceptions of teacher candidates about water. Turkish Studies Educational Sciences, 13(27), 385-404.

Carter, L. (2008). Globalization and science education: Implications of science in the new economy. Journal of Research in Science Teaching, 45(5), 617- 633.

Casey, P. J. \& Scott K. (2006). Environmental concern and behaviour in an Australian sample within an ecocentric - antropocentric framework, Australian Journal of Psychology, 58(2), 57-67.

Chatzifotiou, A. (2006). Environmental education, national curriculum and primary school teachers. Findings of a research study in England and possible implications upon education for sustainable development. The Curriculum Journal, 17(4), 367-381.

Cobanoglu, O. \& Turer, B. (2015). The awareness of science and social science prospective teachers regarding to sustainable environment. International Journal of Turkish Education Sciences, 5, 235-247.

Cohen, L., Manion, L., \& Morrison, K. (2007). Research methods in education. London: Routledge/Falmer.

Collin, P.H. (2004). Dictionary of environment \& ecology. London: Bloomsbury Publishing.

Cross, R. T. (1998). Teachers' views about what to do about sustainable development. Environmental Education Research, 4(1), 41-52.

Effeney, G. \& Davis, J. (2013). Education for sustainability: A case study of preservice primary teachers' knowledge and efficacy. Australian Journal of Teacher Education, 38(5), 3146.

Eilks, I., Nielsen, J. A., \& Hofstein, A. (2014). Learning about the role of science in public debate as an essential component of scientific literacy. In C. Bruguiere, A. Tiberghien, P. Clement (Eds.), Topics and trends in current science education (pp. 85-100). Dordrecht: Springer. 
Ergin, O. (2008). Su farkindaligi uzerine bir egitim projesi. TMOOB 2. Su Politikalari Kongresi Bildiriler Kitabi, 2, 531-540.

Faiz, M. \& Bozdemir Yuzbasioglu, H. (2019). Teacher candidates' awareness of sustainable development. Bolu Abant Izzet Baysal University Journal of Faculty of Education, 19(4), $1255-1271$.

Feldman, A. \& Nation, M. (2015). Theorizing sustainability: An introduction to science teacher education for sustainability. In S.K. Stratton, R. Hagevik, A. Feldman, M. Bloom (Eds.). Educating science teachers for sustainability, (pp.3-13). USA: Springer.

Gunduz, S. \& Bilir, A. (2012). The study of attitude of students in Northern Cyprus for enviromental education and water conservation. Hacettepe University Journal of Education, 1, 225-232.

Haubrich, H., Reinfried, S., \& Schleicher, Y. (2007). Lucerne declaration on geographical education for sustainable development. In S. Reinfried, Y. Schleicher, \& A. Rempfler (Eds.). Geographical views on education for sustainable development. Geographiedidaktische Forschungen, Vol. 42, 243-250, Switzerland.

Hofman-Bergholm, M. (2018). Changes in thoughts and actions as requirements for a sustainable future: A review of recent research on the Finnish educational system and sustainable development. Journal of Teacher Education for Sustainability, 20(2), $19-30$.

Howell, R. \& Cartwright, W. (2009). The ethics of a sustainable economy: Implications for public policy. Paper presented Ethical Foundations of Public Policy Conference, Victoria University, Wellington, New Zealand.

Hungerford, H. R. (2010). Environmental education (EE) for 21st century: Where have we been? Where are we now? Where are we headed? Journal of Environmental Education, 41(1), $1-6$.

Kabadayi, A. (2016). A suggested in-service training model based on Turkish preschool teachers' conceptions for sustainable development. Journal of Teacher Education for Sustainability, 18(1), 5-15.

Karadag A.A. (2008). Problems and solutions for the management of water resources in Turkey. TMMOB 2. Su Politikaları Kongresi Bildiriler Kitabi, 2, 389-400.

Karasar, N. (2002). Scientific research method. Ankara: Nobel Publishing.

Kelly, D. A. \& Fong, D. (2015). Water conservation: the implications of user awareness, attitude, and behaviour. 41st International Symposium of CIB W062 Water Supply and Drainage for Buildings. China: Beijing University of Civil Engineering and Architecture.

Khalid T. (2003). Pre-service high school teachers' perceptions of three environmental phenomena. Environmental Education Research, 9(1), 35-50.

Kortenkamp, K. V., \& Moore, F. C. (2001). Ecocentrism and anthropocentrism: Moral reasoning about ecological commons dilemmas. Journal of Environmental Psychology, 21, 261-272.

McKeown, R., Hopkins, C. A, Rizzi, R., \& Chrystalbride, M. (2002). Education for sustainable development toolkit. Paris: UNESCO.

Miles, M. B. \& Huberman, A. M. (1994). Qualitative data analysis: An expanded source book. Thousand Oaks, CA: Sage.

Ministry of National Education (2018). Science curriculum. Ankara: Board of Education.

Neumayer, E. (2004). Sustainability and well-being indicators. WIDER Research Papers, 2004/23. UNU-WIDER.

Ozmete, E. \& Ozdemir, P. (2015). An analysis on sustainable development indicators in Turkey: social welfare and social services. Society and Social Work, 26(1), 111-130.

Patton, M.Q. (1997). How to use qualitative methods in evaluation. Newbury Park, CA: SAGE Publications.

Powers, A. L. (2004). Teacher preparation for environmental education: Faculty perspectives on the infusion of environmental education into preservice methods courses. The Journal of Environmental Education, 35, 3-11. 
Salite, I. (2008). Educational action research for sustainability: Constructing a vision for the future in teacher education. Journal of Teacher Education for Sustainability, 10, 5-17.

Salite, I. (2015). Searching for sustainability in teacher education and educational research: Experiences from the Baltic and Black Sea Circle Consortium for educational research. Discourse and Communication for Sustainable Education, 6, 21-29.

Stratton, S. K., Hagevik, R., Feldman, A., \& Bloom, M. (Eds.). (2015). Educating science teachers for sustainability. New York: Springer.

Sama, E. (2003). Teacher candidates' attitudes toward environmental problems. Gazi University Journal of Gazi Educational Faculty, 23(2), 99-110.

Tanriverdi, B. (2009). Analyzing primary school curriculum in terms of sustainable environmental education. Education and Science, 34(151), 89-103.

Tietenberg, T. (2006). Environmental and natural resource economics. New York: HarperCollins Publishers.

Tindall, D. B., Davies, S., \& Mauboules, C. (2003). Activism and conservation behavior in an environmental movement: The contradictory effects of gender. Society \& Natural Resources, 16(10), 909-932.

Tokicin U.B., Kurnaz, M. A. ve Yuzbasioglu, M. K. (2020). Self-efficacy belief scale development study about different representations. Kirklareli University Journal of Social Sciences, 4(1), 1-19.

Tuncer, G., Ertepinar, H., Tekkaya, C., \& Sungur, S. (2005). Environmental attitudes of young people in Turkey: effects of school type and gender. Environmental Education Research, 11(2), 215-233.

Turkish Republic Presidency of Strategy and Budget (2019). Sustainable development goals assessment report. Retrieved from

https://sustainabledevelopment.un.org/content/documents/23862Turkey_VNR_110719. pdf

United Nations Development Programme (2015). Sustainable development goals. Retrieved from https://www.undp.org/content/undp/en/home/sustainable-developmentgoals.html

Urey, M., Colak, K., Bozdemir Yuzbasioglu, H., \& Kaymakci, S. (2020). Comparison of prospective science and social studies teachers' knowledge levels of and misconceptions about atmospheric environmental problems. International Electronic Journal of Environmental Education, 10(2), 216-236.

Veisson, M. \& Kabadayi, A. (2018). Exploring the preschool teachers' views on professionalism, quality of education and sustainability: international study in Estonia and Turkey. Journal of Teacher Education for Sustainability, 20(2), 5-18.

Walls, A., E. J. (2011). Learning our way to sustainability. Journal of Education for Sustainable Development, 5(2), 177-186.

Yaz, O. V, Yuzbasioglu, M. K. \& Kurnaz, M. A. (2019). Comparative analysis of the changes of the subject / learning field of the science curriculum for the year 2000 and after. International Conference on Science, Mathematics, Entrepreneurship and Technology Education. Turkey: Izmir.

Yaz, O.V. \& Kurnaz, M.A. (2020). Comparative analysis of the science teaching curricula in Turkey, SAGE Open, 10(1), 1-14

Yuzbasioglu, M. K. \& Kurnaz, M. A. (2019). Determination of self-efficiency beliefs of science teacher candidates for teaching astronomy issues. International Marmara Social Sciences Congress. Turkey: Kocaeli.

Zelezny, L. C., Chua, P. P., \& Aldrich, C. (2000). Elaborating on gender differences in environmentalism. Journal of Social Issues, 56(3), 443-457. 


\section{Appendix A}

UN 2030 Sustainable Development Goals (UNDP, 2015)
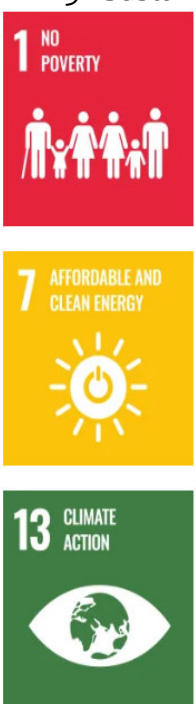

Goal

G1

G2

G3

G4

G5

G6

G7

G8

G9

G10

G11 Make cities and human settlements inclusive, safe, resilient and sustainable.

G12 Ensure sustainable consumption and production patterns.

G13 Take urgent action to combat climate change and its impacts.

G14
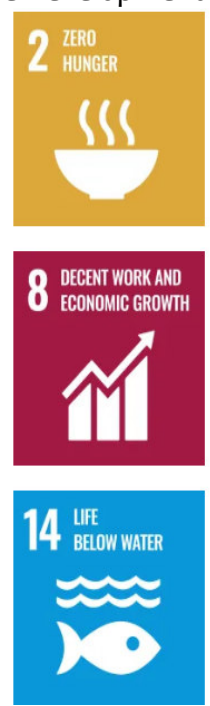

Explanation
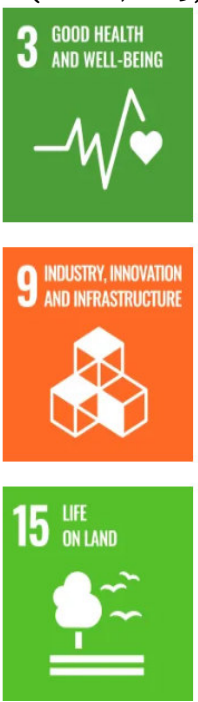

End poverty in all its forms everywhere.

End hunger, achieve food security and improved nutrition and promote sustainable agriculture.

Ensure healthy lives and promote well-being for all at all ages.

Ensure inclusive and equitable quality education and promote lifelong learning opportunities for all.

Achieve gender equality and empower all women and girls.

Ensure availability and sustainable management of water and sanitation for all.

Ensure access to affordable, reliable, sustainable and modern energy for all.

Promote sustained, inclusive and sustainable economic growth, full and productive employment and decent work for all.

Build resilient infrastructure, promote inclusive and sustainable industrialization and foster innovation.

Reduce inequality within and among countries.

Conserve and sustainably use the oceans, seas and marine resources for sustainable
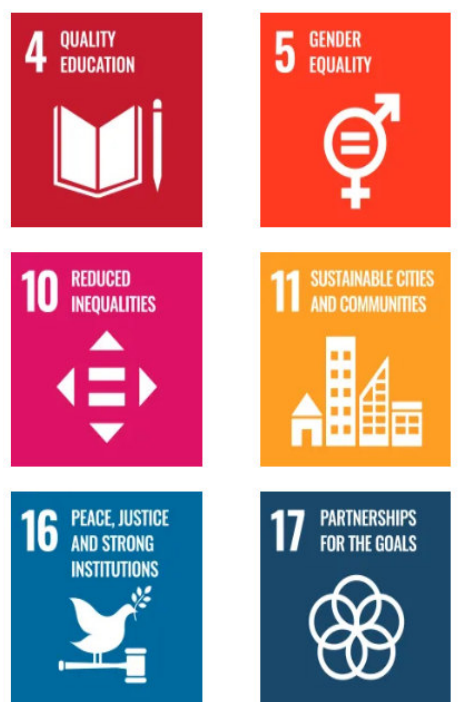

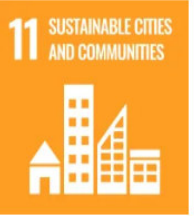

17 PARTNERSHIPS FOR THE GOALS

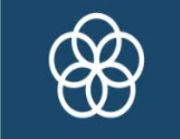
development. 
G15

Protect, restore and promote sustainable use of terrestrial ecosystems, sustainably manage forests, combat desertification, and halt and reverse land degradation and halt biodiversity loss.

G16

Promote peaceful and inclusive societies for sustainable development, provide access to justice for all and build effective, accountable and inclusive institutions at all levels.

G17

Strengthen the means of implementation and revitalize the global partnership for sustainable development.

\section{Biographical notes:}

Mustafa Kemal YÜZBAȘIOĞLU is a PhD student at Kastamonu University, Institute of Science, Department of Mathematics and Science Education. His current research interests are science education, models and modelling, sustainable development, context-based learning, comics.

Dr. Mehmet Altan KURNAZ is a Professor in the Department of Mathematics and Science Education at Kastamonu University, Turkey. His current research interests are physics education, science education, grounded mental model theory, models and modelling, alternative ideas, context-based learning. 